\title{
A SOCIOLINGUISTIC STUDY ON JOKE IN GHOSTBUSTERS 2016 MOVIE
}

\author{
Dewi Syafitri ${ }^{1}$ \\ STKIP-PGRI Lubuklinggau \\ Maharani Robiatul Islam ${ }^{2}$ \\ STKIP-PGRI Lubuklinggau \\ dewisyafitristkipllg@gmail.com ${ }^{1}$
}

Submit, 20-04-2018 Accepted, 31-05-2018 Publish, 31-05-2018

\begin{abstract}
The objectives of the research were to describe the forms and the functions of joke in Ghostbusters 2016 movie. The researcher used descriptive qualitative method in classifying and analyzing the forms and functions of joke. Ghostbusters 2016 movie was chosen as object of the research. The researcher used documentation in collecting the data. Technique for analyzing the data was identification, classification, reduction, description and conclusion. The result of the research: 1) form; 5 words (proper noun, determiner, uncountable noun), 7 phrases (prepositional phrase, noun phrase, verb phrase), and 59 sentences (simple sentence, complex sentence, compound sentence, imperative sentence, exclamatory sentence). 2) function; joke to build sense of togetherness in informal setting that was used in close relationship 10 jokes, joke to amuse others and her/him self in informal setting that was used in close relationship 22 jokes, joke to hostile others with violent behavior and teasing in informal setting that was used in distant relationship 10 jokes. In brief, the most frequent form and function was used in Ghostbusters 2016 movie was simple sentence and using joke to amuse others and her/him self in informal setting that was used in close relationship was the most frequent used in Ghostbusters 2016 movie.
\end{abstract}

Keyword: sociolinguistics, joke, comedy movie, ghostbusters

\section{INTRODUCTION}

Sociolinguistics is the study of language that focuses on language use and language development in society. According to Aronoff and Miller (2001: 563), sociolinguistics is the empirical study of how language is used in society. It explains why we spoke differently in different social contexts and it concerns in identifying the social functions of language and how the ways it is used to convey the meaning.

There are social factors which influence the language use. They are participants, setting or social context, topic and function. In using language in 
conversation, speaker and listener must understand each other and make their conversation is not bored. If speaker can dominate the conversation by using funny words, it can make the hearer feel enjoyment and the speaker can get more attention from the hearer. Joke is one of the ways to make their conversation is not bored and it will make their conversation more interesting and enjoying.

A joke is an orderly sequence of sentences (written or spoken) working as a unit intentionally used by a speaker to amuse the hearer (Ahmadvand \& Dastejerdi, 2013: 54). Joke is part of language and also part of humor. According to Villevort (2014: 2), jokes are part of our everyday language, it cannot be taken for granted that joke always understood correctly. Joke can be found everywhere. It may appear in novels, movies or in everyday conversation and in movies, the most jokes are found in comedy movie. Comedy movie is genre of movie that emphasizes humor and joke. Comedy movie can make people feeling enjoyable.

In movies, the most joke is found in comedy movie. Comedy movie is genre of movie that emphasizes humor and joke. Comedy movie can make people feeling enjoyable. According to Patrika (n.d), the importance of jokes is joke can bring laughter to the people who are listening or watching especially when people around us feel sad, are in a serious mood or have a problem. Joke means to amuse and make people laugh. Based on Cole (2013:23), laughter is the best medicine. Laughter also prevents heart disease, low stress and anxiety levels dramatically, and enhances our resilience to harsh situations.

In this research, the researcher analyzed joke in Ghostbusters 2016 movie. It was comedy movie in 2016. According to D'Alessandro (2016:90), Ghostbusters 2016 includes on top 10 films and notables according to industry estimates for the weekend of July 15-17. It is also reboot Ghostbusters 2. According to Asih (2016:45), Ghostbusters 2016 includes on top 10 popular movies in 2016 version IMDb. Ghostbusters 2016 movie is different with Ghostbusters 2, all the actors are woman in Ghostbusters 2016 movie. This movie tells about struggle of woman in catching the ghosts and rescuing the country from the ghosts with funny action and jokes.

\section{LITERATURE REVIEW}

Sociolinguistics is concerned with investigating the relationship between language and society with the goal being a better understanding of the structure of language and how languages function in communication (Wardhaugh, 2006: 13). Sociolinguistics is also study of the ways people use language in social interaction.

In using language in conversation, speaker and listener must understand each other and make their conversation is not bored. If speaker can dominate the conversation by using funny words, it can make the hearer feel enjoyment and the 
speaker can get more attention from the hearer. Through joke, the conversation between listener and hearer become more interesting, lively and spirited.

Joke can be found everywhere. It can appear in novel, movie or in everyday conversation (Giusti \& Budiharjo, 2015: 11). Based on Martin (2013: 38), a joke is something people do or say that will bring laughter to the people who are watching. In joke, there are verbal and non verbal. Verbal joke is jokes communication by using spoken words and it is mostly face-to-face or written with the use of language as a means. Meanwhile, non verbal joke is jokes communication by using visual cues such as using body language, gestures and facial expressions. Laughter is the best medicine and in order to provoke laughter. A joke generally requires some relevant background knowledge in order to understand the humor (Yates \& Hasmath, 2016: 1). It means to understand jokes people have to know the background knowledge of the words or language that spoken. People would know whether it is joke or not can be seen based on joke theory by expert. Based on Meyer (2000: 310), there are three theories of humor. They are relief theory, incongruity theory and superiority theory.

In this resaerch, the researcher only focused on lexical and syntax in analyzing forms of joke. Lexicon is the ability to use any word in a sentence requires knowledge of its lexical category. There are several ways to help identify the lexical category of a word. According to Richards and Schmidt (1985: 636), word is the smallest of the linguistic unit which can occur on its own in speech or writing. Based on Carnie (2013: 48), the word has some major classes such as noun, verb, adjective, adverb, preposition and determiner.

Syntax is the study about phrases and sentences in language. According to Davidson (2003: 68), a phrase is any group of two or more words that can occupy the same slot in sentence as a single word. According on Carnie (2013: 74), the phrase has some classes. They are verb phrase, noun phrase, adverb phrase, adjective phrase and prepositional phrase. A sentence is a group of words that is used to make a statement, to ask a question, or to give an order or make a request (Davidson, 2003: 2). There are kinds of sentence such as simple sentence, complex sentence, compound sentence, imperative sentence, exclamatory sentence, interrogative sentence and declarative sentence.

Based on Berger (1995: 14), there are some functions of joke. They are:

1. Telling the joke helps build a sense of togetherness, helps integrate the teller and the listener into a group those listening to the joke.

2. Telling the joke is to amuse others, to be looked upon favorably as someone who has a sense of humor, who is amusing and entertaining. We can say this about joke telling in general. 
3. Telling joke is to establish more strongly, to firm up the teller's and listener's heterosexual identity, to demonstrate that one is normal by laughing at those who are supposedly not normal who are deviant.

4. Telling this joke can be seen as a functional alternative to hostile and perhaps even violent behavior.

In this research, the functions of jokes were based on setting and participant. Setting is the place where people used jokes. It can be formal setting and informal setting. Participant is people that used jokes. Participants can be friend-friend, boss-workers, students-teacher. It means they are in close relationship or distant relationship (Holmes, 2013: 9).

\section{RESEARCH METHOD}

In this research, the researcher used descriptive qualitative method. Based on Fraenkel and Wallen (2009: 422), qualitative research is research studies that investigate the quality of relationships, activities, situations, or materials. Qualitative research is a means for exploring and understanding the meaning individuals or groups ascribe to a social or human problem (Creswell, 2009: 4).

In this research, there were two sources of the data in this research. They were primary source and secondary source. The primary source was taken from Ghostbusters 2016 movie with English subtitle and the secondary source was taken from books, journal, dictionary and articles from internet relate to this research.

In collecting the data, the researcher used documentation analysis for collecting the data. The process of collecting the data consisted of the following steps. First, the researcher watched Ghostbusters 2016 movie. Second, the researcher transcribed English subtitle of Ghostbusters 2016 movie into papers. The last, the researcher classified and transferred joke that used by the speakers in Ghostbusters 2016 movie into the data sheet.

After data was collected, the researcher analyzed forms and functions of joke in Ghostbusters 2016 movie. In analyzing the data, there were some steps were used by the researcher, they were identification, classification, reduction, description and conclusion.

\section{FINDING}

There were some findings in this research including the forms and the functions of joke were used by the speakers in Ghostbusters 2016 movie. The functions of joke were analyzed based on setting and participant. 


\section{The Forms of Joke Found in Ghostbusters 2016 Movie}

The form of joke was focused on lexicon and syntax. They were words, phrases and sentences. Based on forms of joke were used by the speakers in Ghostbusters 2016 movie. There were kinds of word, phrase and sentence of joke in Ghostbusters 2016 movie.

The researcher had calculated the forms of joke in Ghostbusters 2016 movie, there were: 5 words, 7 phrases and 59 sentences. In word, there were three kinds of word found in Ghostbusters 2016 movie. They are proper noun (2 utterances), determiner ( 2 utterances), and uncountable noun (1 utterance). In phrase, there were three kinds of phrase found in Ghostbusters 2016 movie. They were noun phrase (1 utterance), prepositional phrase ( 2 utterances) and verb phrase (4 utterances). In sentences, there were five kinds of sentence. They were simple sentence (38 utterances), complex sentence (11 utterances), compound sentence (1 utterance), imperative sentence (6 utterances) and exclamatory sentence (3 utterances).

Among 3 forms of joke, sentence (simple sentence) was the most frequent used in Ghostbusters 2016 movie. The researcher found several kinds of forms of joke in Ghostbusters 2016 movie can be seen in the table below:

Table 1. Total Forms of Joke in Ghostbusters 2016 Movie

\begin{tabular}{|c|c|c|c|}
\hline Forms of Joke & Kinds & Number & Total \\
\hline \multirow[t]{3}{*}{ Word } & Proper Noun & 2 & \\
\hline & Determiner & 2 & 5 \\
\hline & Uncountable Noun & 1 & \\
\hline \multirow[t]{3}{*}{ Phrase } & Noun Phrase & 1 & \\
\hline & Preposition Phrase & 2 & 7 \\
\hline & Verb Phrase & 4 & \\
\hline \multirow[t]{9}{*}{ Sentence } & Simple Sentence & & \\
\hline & a. Declarative Sentence & 25 & \\
\hline & b. Interrogative Sentence & 6 & \\
\hline & c. Negative Sentence & 4 & 59 \\
\hline & d. WH Question & 3 & \\
\hline & Complex Sentence & 11 & \\
\hline & Compound Sentence & 1 & \\
\hline & Imperative Sentence & 6 & \\
\hline & Exclamatory Sentence & 3 & \\
\hline
\end{tabular}


From the table above, the researcher had calculated the total forms of joke in Ghostbusters 2016 movie. There were some forms of joke as the most used in Ghostbusters 2016 movie: word 2 (proper noun and determiner), phrase 4 (verb phrase) and sentence 38 (simple sentence). Among 3 forms of joke, sentence (38 simple sentences) was the most frequent used in Ghostbusters 2016 movie.

Here are the examples of forms of joke in Ghostbusters 2016 movie including word forms, phrases, and sentences:

1. Word Forms

The following table presented word forms of joke in Ghostbusters 2016 movie.

Table 2. Word Forms of Joke in Ghostbusters 2016 Movie

\begin{tabular}{ccccc} 
No & Kinds of Word & Words & Time & Theory of Joke \\
\hline 1 & Proper Noun & Bennie & $00: 11: 17$ & Incongruity \\
\hline 2 & Determiner & $\begin{array}{c}\text { Sixty. } \\
\text { Seventy }\end{array}$ & $00: 22: 53$ & Incongruity \\
& & Salad & $01: 24: 14$ & Incongruity \\
\hline 3 & Uncountable Noun & & & \\
\hline 4 & Determiner & 2040 & $01: 58: 10$ & Incongruity
\end{tabular}

From the table above, the researcher found word forms of joke in Ghostbusters 2016 movie. There were three kinds of word. They were proper noun, determiner, and uncountable noun.

2. Phrase Forms

The following table presented phrase forms of joke in Ghostbusters 2016 movie.

Table 3. Phrase Forms of Joke in Ghostbusters 2016 Movie

\begin{tabular}{cclcc} 
No & $\begin{array}{c}\text { Kinds of } \\
\text { Phrase }\end{array}$ & \multicolumn{1}{c}{ Phrases } & Time & $\begin{array}{c}\text { Theory of } \\
\text { Joke }\end{array}$ \\
\hline 1 & Prepositional & No, in the portal & $02: 02: 21$ & Incongruity \\
\hline 2 & Noun & $\begin{array}{l}\text { Incredibly } \\
\text { immature } \\
\text { behavior }\end{array}$ & $00: 26: 04$ & Superiority \\
& & & \\
\hline 3 & Verb & $\begin{array}{l}\text { Makes you look } \\
\text { a lot older }\end{array}$ & $01: 59: 08$ & Superiority \\
& & &
\end{tabular}


From the table above, the researcher found phrase forms of joke in Ghostbusters 2016 movie. There were three kinds of phrase. They were prepositional phrase, verb phrase and noun phrase.

3. Sentence Forms

The following table presented sentence forms of joke in Ghostbusters 2016 movie.

Table 4. Sentence Forms of Joke in Ghostbusters 2016 Movie

\begin{tabular}{|c|c|c|c|c|}
\hline No & $\begin{array}{l}\text { Kinds of } \\
\text { Sentence }\end{array}$ & Sentences & Time & $\begin{array}{c}\text { Theory of } \\
\text { Joke }\end{array}$ \\
\hline 1 & Simple Sentence & $\begin{array}{l}\text { That man went out } \\
\text { the wrong door }\end{array}$ & 01:09:41 & Incongruity \\
\hline 2 & Simple Sentence & $\begin{array}{l}\text { This is what you're } \\
\text { wearing? }\end{array}$ & $00: 05: 49$ & Superiority \\
\hline 3 & Simple Sentence & $\begin{array}{l}\text { How can you be } \\
\text { eating right now? }\end{array}$ & $00: 19: 58$ & Incongruity \\
\hline 4 & Simple Sentence & $\begin{array}{l}\text { No, I was just not } \\
\text { into that } \\
\text { conversation }\end{array}$ & $00: 44: 41$ & Incongruity \\
\hline 5 & $\begin{array}{l}\text { Complex } \\
\text { Sentence }\end{array}$ & $\begin{array}{l}\text { Is it the boobs you } \\
\text { don't like? Cause I } \\
\text { can make them } \\
\text { bigger }\end{array}$ & 00:35:08 & Incongruity \\
\hline 6 & $\begin{array}{l}\text { Complex } \\
\text { Sentence }\end{array}$ & $\begin{array}{l}\text { She thinks they're } \\
\text { all doors }\end{array}$ & $01: 35: 20$ & Superiority \\
\hline 7 & $\begin{array}{l}\text { Compound } \\
\text { Sentence }\end{array}$ & $\begin{array}{l}\text { He is half as stupid } \\
\text { and he will work } \\
\text { for } \\
\text { sausages }\end{array}$ & $00: 45: 06$ & Superiority \\
\hline 8 & $\begin{array}{c}\text { Imperative } \\
\text { Sentence }\end{array}$ & $\begin{array}{l}\text { Pin it to your bra } \\
\text { strap }\end{array}$ & $01: 29: 53$ & Relief \\
\hline 9 & $\begin{array}{c}\text { Exclamatory } \\
\text { Sentence }\end{array}$ & Fuck you & $00: 30: 19$ & Incongruity \\
\hline
\end{tabular}

From the table above, the researcher found sentence forms of joke in Ghostbusters 2016 movie. There were five kinds of sentence. They were simple sentence, complex sentence, compound sentence, imperative sentence and exclamatory sentence. 


\section{The Functions of Joke Found in Ghostbusters 2016 Movie}

The functions of joke were used by the speakers in Ghostbusters 2016 movie based on setting and participant. They are jokes to build sense of togetherness, jokes to amuse others and her/him self and jokes to hostile others with violent behavior and teasing.

From the movie the researcher found three functions of joke based on setting and participant in Ghostbusters 2016 movie can be seen in the table below:

Table 5. Total Functions of Joke in Ghostbusters 2016 Movie

\begin{tabular}{|c|c|c|c|c|}
\hline $\begin{array}{c}\text { Functions of } \\
\text { Joke }\end{array}$ & Setting & Participant & Number & Total \\
\hline \multirow{3}{*}{$\begin{array}{l}\text { To build sense } \\
\text { of togetherness }\end{array}$} & Formal & Close Relationship & 1 & \multirow{3}{*}{15} \\
\hline & Informal & Close Relationship & 10 & \\
\hline & Informal & Distant Relationship & 4 & \\
\hline \multirow{4}{*}{$\begin{array}{l}\text { To amuse others } \\
\text { and her/himself }\end{array}$} & Formal & Distant Relationship & 2 & \multirow{4}{*}{37} \\
\hline & Informal & Distant Relationship & 11 & \\
\hline & Formal & Close Relationship & 2 & \\
\hline & Informal & Close Relationship & 22 & \\
\hline \multirow{3}{*}{$\begin{array}{l}\text { To hostile others } \\
\text { with violent } \\
\text { behavior and } \\
\text { teasing }\end{array}$} & Informal & Distant Relationship & 10 & \multirow{3}{*}{19} \\
\hline & Formal & Distant Relationship & 5 & \\
\hline & Informal & Close Relationship & 4 & \\
\hline
\end{tabular}

From the table above, the researcher had calculated the total functions of joke in Ghostbusters 2016 movie. There were three functions of joke as the most used in Ghostbusters 2016 movie: jokes to build sense of togetherness in informal setting that were used in close relationship (10 jokes), jokes to amuse others and her/himself in informal setting that were used in close relationship (22 jokes) and jokes to hostile others with violent behavior and teasing in informal setting that were used in distant relationship (10 jokes).

\section{DISCUSSION}

There are two ways in communication namely communication by using language and gestures. Language is used in conversation. In conversation, speaker and hearer must understand each other and they have to make their conversation is not bored. If speaker can dominate the conversation by using funny words, it can make the hearer feel enjoyment and the speaker can get more attention from the hearer. Joke is one of the ways to make their conversation is not bored. According 
to Villevort (2014: 2), jokes are part of our everyday language, it cannot be taken for granted that joke always understood correctly. Jokes is needed in conversation to make the conversation more interesting and enjoying.

Based on Meyer (2000: 310), there are three theories of joke. They are relief theory, incongruity theory and superiority theory. Based on three theories of joke by Meyer, people will know whether it was joke or not and also whether it was funny or not. But if it included in three theories of joke, it was still joke based on Meyer's theory. Based on Martin (2013: 38), a joke is something people do or say that will bring laughter to the people who are watching. Jokes mean to amuse and make people laugh. A joke is an orderly sequence of sentences (written or spoken) working as a unit intentionally used by a speaker to amuse the hearer (Ahmadvand \& Dastejerdi, 2013: 54).

A joke generally requires some relevant background knowledge in order to understand the humor (Yates \& Hasmath, 2016: 1). It means to understand jokes people have to know the background knowledge of the words or language that spoken. Joke can be found everywhere. It may appear in novel, movie or in everyday conversation (Giusti \& Budiharjo, 2015: 11). In this research, the researcher analyzed jokes in movie. In movie, the most jokes was found in comedy movie. Comedy movie made people feeling enjoyble. Comedy movie was chosen in this research was Ghostbusters 2016 movie. In Ghostbusters 2016 movie, there were 71 jokes that were found. Mostly, jokes were used by the speakers in Ghostbusters 2016 movie was unusual language and coarse language. That language made people laugh and surprised when they heard it.

In this research, the researcher analyzed forms and functions of joke. In forms of joke, the researcher focused on lexicon and syntax. Lexicon is the ability to use any word in a sentence requires knowledge of its lexical category. Syntax is the study about phrases and sentences in language.

\section{The Forms of Joke Found in Ghostbusters 2016 Movie}

The result of the data, there were three forms of joke in Ghostbusters 2016 movie based on linguistic form. They were word, phrase and sentence. According to Richards and Schmidt (1985: 639), word is the smallest of the linguistic unit which can occur on its own in speech or writing. The most frequent word used was proper noun and determiner (2 jokes). Proper noun and determiner were used by the speakers because it was simple word that surprised others and reduced tension for someone who felt stress. For example: Sweetie. This joke used by Patty to reduce tension and surprise others when they heard it.

According to Davidson (2003: 68), a phrase is any group of two or more words that can occupy the same slot in sentence as a single word. The most frequent phrase used was verb phrase (4 jokes). Verb phrase was used by the 
speakers because the speakers can insult and mock someone by using verb phrase. The speakers did not need complete sentence to mock and insult someone. They said the point directly. For example: "Hope this guy knows how to ride motorcycle". This joke used by Rowan. Rowan thought the guy (Kevin) cannot ride motorcycle. So, Rowan mocked and insulted Kevin directly without used complete sentence. It had been clear when Rowan said "Hope this guy knows how to ride motorcycle". Rowan were insulting Kevin and Rowan felt he can ride motorcycle than Kevin.

According to Davidson (2003: 2), a sentence is a group of words that is used to make a statement, to ask a question, or to give an order or make a request. Simple sentence was the most frequent sentence used by actor and actress in in Ghostbusters 2016 movie (38 jokes). Simple sentence was used by the speakers because the speakers can used joke by using some ways. It can be statement, ask questions and others. In simple sentence, the speakers surprised others by using funny statements. It can be positive sentence, negative sentence, interrogative sentence and unusual language that include in sentence. For Example: "Our president is a plant". This joke was used by Holtzmann. That statement surprised people surroundings because it was impossible if human was a plant or human became a plant. Human and plant were different each other.

According to Brandon (2014: 30), a simple sentence consists of one independent clause and no dependent clause. It may contain phrases and have more than one subject or verb. Sentences are used in four different ways for example to ask questions, to issue commands or to make exclamations (Lester \& Beason, 2013: 37). The most frequent way used in simple sentence was declarative sentence (25 jokes). Declarative sentences are used for making statements. Declarative sentences can be positive or negative (Lester \& Beason, 2013: 37).

\section{The Functions of Joke Found in Ghostbusters 2016 Movie}

Based on Berger (1995: 14), there are some functions of joke. Functions of jokes were based on setting and participant. Setting is the place where people used jokes. It can be formal setting and informal setting. Participant is people that used jokes. Participants can be friend-friend, boss-workers, and student-teacher. It means they are in close relationship or distant relationship (Holmes, 2013: 9). Every functions of joke were different meaning based on setting and participant.

1. Telling the joke helps build a sense of togetherness, helps integrate the teller and the listener into a group those listening to the joke.

2. Telling the joke is to amuse others, to be looked upon favorably as someone who has a sense of humor, who is amusing and entertaining. We can say this about joke telling in general. 
3. Telling joke is to establish more strongly, to firm up the teller's and listener's heterosexual identity, to demonstrate that one is normal by laughing at those who are supposedly not normal who are deviant.

4. Telling this joke can be seen as a functional alternative to hostile and perhaps even violent behavior.

After analyzing Ghostbusters 2016 movie, the researcher found three functions of joke were used by the speakers in Ghostbusters 2016 movie based on setting and participant; 1) jokes to build sense of togetherness with others in formal setting that was used in close relationship, in informal setting that was used in close relationship and in informal setting that was used in distant relationship, 2) jokes to amuse others and her/himself in formal setting that was used in distant relationship, in informal setting that was used in distant relationship, in formal setting that was used in close relationship and in informal setting that was used in close relationship, 3) jokes to hostile others with violent behavior and teasing in informal setting that was used in distant relationship, in formal setting that was used in distant relationship and in informal setting that was used in close relationship.

The most frequent functions of joke was used by the speakers in Ghostbusters 2016 movie based on setting and participant; 1) jokes to build sense of togetherness in informal setting that was used in close relationship (10 jokes). For example: "Our president is a plant". This jokes was used by Holtzmann in answering Erin's question. In this function, they used jokes to tighten their relationship more. They did not have limitation in using jokes because they had known each others. They were in close relationship. They also used jokes without thinking whether the joke was coarse or not because they had known how they used joke with people who were really close with them to build sense of togetherness (Holmes, 2013:9), 2) jokes to amuse others and her/himself in informal setting that was used in close relationship (22 jokes). For example: "You were never invited! I need you out of the lab, so I can lock the door". This jokes used by Abby to ask Erin to get out from her lab because Abby wanted to go to Aldridge Mansion and lock the door, but Erin was in wrong perception. Erin thought that Abby asked her to go to Aldridge Mansion with Abby and Holtzmann. In this function, they used jokes to amuse people surroundings. The jokes were used by people who had close relationship because they had high solidarity (Holmes, 2013: 9). There were not embarrassed feeling in using taboo word, swear words and unusual language that can amuse people surroundings and they did not feel distant in using jokes, 3) jokes to hostile others with violent behavior and teasing in informal setting that was used in distant relationship (10 jokes). For example: "She thinks they're all doors". This joke was used by Ms. Lynch to Erin. They insulted Erin because Erin's strange behavior so Ms. Lynch 
said "She thinks they're all doors". In this function, they used jokes to insult people who had distant relationship. They were braver to insult people who had distant relationship because they did not have bond in relationship (Holmes, 2013: 9). In briefly, the most frequent function of joke was used by the speakers in "Ghostbusters 2016" movie was using jokes to amuse others and her/himself in informal in terms of close relationship because they did not feel distant each other in amusing by using jokes. They also did not have limitation in using jokes because they had known each other so they were free in using jokes and amusing others. They also had high solidarity each other so they were not shy or afraid in using taboo word, swear words and unusual language.

This research could be used as the material in teaching joke more deeply especially in understanding of joke. Those could make the student know how joke are used in society especially in learning process. The topic of the research was about forms and functions of joke in sociolinguistics. This research explained more about joke and it also explained about how people know whether it was joke or not by using Mayor's theory of joke. So this result also can be used in teaching sociolinguistics and it can help the students know and understand more about joke.

\section{CONCLUSION}

The research aimed to describe the forms of joke and the functions of joke were used by the speakers in Ghostbusters 2016 movie. After analyzed Ghostbusters 2016 movie, the researcher concluded this research as follows: The researcher found some kinds of forms of joke in movie transcription as follow: 5 words (proper noun, determiner, uncountable noun), 7 phrases (prepositional phrase, noun phrase, verb phrase), and 59 sentences (simple sentence, complex sentence, compound sentence, imperative sentence, exclamatory sentence). Among 3 forms of joke, simple sentence was the most frequent used in Ghostbusters 2016 movie.

There were three functions of joke were used by the speakers in Ghostbusters 2016 movie: 1) joke to build sense of togetherness with others (15 jokes); 2) joke to amuse others and her/himself (37 jokes); 3) joke to hostile others with violent behavior and teasing (19 jokes). The most frequent functions of joke were used by the speakers in Ghostbusters 2016 movie based on setting and participant: 1) jokes to build sense of togetherness in informal setting that were used in close relationship (10 jokes); 2) jokes to amuse others and her/himself in informal setting that were used in close relationship (22 jokes); 3 ) jokes to hostile others with violent behavior and teasing in informal setting that were used in distant relationship (10 jokes). Among 3 functions of joke were used by the speakers in Ghostbusters 2016 movie based on setting and participant, using jokes 
to amuse others and her/him self in informal setting that were used in close relationship was the most frequent used in Ghostbusters 2016 movie.

\section{REFERENCES}

Ahmadvand, M., \& Dastejerdi, H. V. (2013). Discourse analysis of sms jokes: A crosscultural comparison of joke strategies in Persian and English. Malaysian Journal of Media Studies, 15(1), 51-73.

Aronoff, M., \& Miller, J. R. (2001). The handbook of linguistics. Oxford: Blackwell Publishing.

Asih, R. (2016). 10 film terpopuler tahun 2016 versi IMBd. Retrieved from http://showbiz.liputan6.com/read/2683672/10-film-terpopuler-tahun-2016versi-imdb.

Berger, A. A. (1995). Blind men and elephants: Perspectives on humor. New Brunswick and London: Transaction Pubslishers.

Carnie, A. (2013). Syntax: A Generative Introduction (3rd ed.). Oxford: WileyBlackwell.

Cole, J. (2013). Laughter is the best medicine: The importance of live comedy [Web log post]. Retrieved from http://www.newschoolfreepress.com/2013/05/07/laughter-is-the-bestmedicine-the-importance-of-live-comedy/.

Creswell, J. W. (2009). Research design (3rd ed.). Los Angeles: SAGE Publication, Inc.

Davidson, G. (2003). Phrases, Clauses and Sentences. Tagore Lane, Singapore: Leraners Publishing.

D'Alessandro, A. (2016). 'Ghostbusters': how its \$46M opening creates a quandary - weekend box office postmortem. Retrieved from http://deadline.com/2016/07/ghostbusters-weekend-box-office 1201787149/

Fraenkel, J. R., \& Wallen, N. E. (2009). How to design and evaluate research in education (7th ed.). New York: McGraw-Hill Company.

Guisti, N, R and Budiharjo, B. (2015). An Analysis of Joke Translation in Date Night Movie. Jurnal Bahasa, Sastra dan Studi Amerika, 21(1), 11-17.

Holmes, J. (2013). An introduction to sociolinguistics (4th ed.). New York: Routledge.

Martin, S. (2013). Humorous text: A pragmatic analysis of lubukusu joke (Undergraduate thesis). University of Nairobi, Kenya. Retrieved from http://erepository.uonbi.ac.ke:8080/xmlui/bitstream/handle/11295/63124/ situma_Humorous $\% 20$ texts $\% 3 \mathrm{~A} \% 20 \mathrm{a} \% 20$ pragmatic $\% 20$ analysis $\% 20 \mathrm{of} \%$ 20Lubukusu $\% 20$ Jokes $\% 20$ ? sequence $=3 \&$ isAllowed $=\mathrm{y}$

Meyer, J. C. (2000). Humor as a double-edged sword: Four functions of humor in communication. Communication Theory 10(3), 310-331. Retrieved from http://econoca.unica.it/public/downloaddocenti/MEYER\%20$\% 20$ FOUR\%20FUNCTIONS\%20OF\%20HUMOR\%20IN\%20COMMUN ICATION.pdf 
Patrika, R. (n.d). What is the importance of jokes in our daily life [Web log post]. Retrieved from https://medium.com/@rajasthanpatrika01/what-isthe- importance-of-jokes-in-our-daily-life-987ca276943a\#.hebjo01bz

Richard, J. C, \& Schmidt, R. (1985). Longman Dictionary of Applied Linguistics. Harlow, Essex: Longman Group Limited.

Villevort, V. (2014). Cultural aspects of language.understanding jokes. pp. 13. Retrieved from http://www.academia.edu/7590586/CULTURAL_ASPECTS_OF_LANG UAGE_Understanding_Jokes_Term_Paper_Language_in_Use_SS_2013 14_Table_of_Contents.

Wardhaugh, R. (2006). An introduction to sociolinguistics. Oxford: Blackwell Publishing.

Yates, M., \& Hasmath, R. (2016). When a joke is more than a joke: Humor as a form of networked practice in the chinese cyber public sphere. Retrieved from https://papers.ssrn.com/sol3/papers.cfm?abstract_id=2672446 